Original Research

\title{
Comparison of Measured and Modelled Traffic-Related Air Pollution in Urban Street Canyons
}

\author{
Audrius Dėdelė*, Auksė Miškinytė, Irma Česnakaitė \\ Department of Environmental Sciences, Faculty of Natural Sciences, \\ Vytautas Magnus University, Kaunas, Lithuania
}

Received: 13 June 2018

Accepted: 24 July 2018

\begin{abstract}
The level of hazardous traffic pollutants, such as nitrogen dioxide $\left(\mathrm{NO}_{2}\right)$, significantly increases in street canyons, which is a relevant determinant of assessing human exposure and health risks and deteriorates quality of urban air. The aim of the present study was to measure air pollution of $\mathrm{NO}_{2}$ by passive samplers in five street canyon sites with different traffic and building characteristics during two-week measurement periods in each season and to compare measured $\mathrm{NO}_{2}$ concentrations with models using the Airviro street canyon model. The data of meteorological parameters, street canyon orientation and urban background air pollution were taken into account. The study results showed that the highest measured and modelled concentrations of $\mathrm{NO}_{2}$ in street canyons were determined during spring and summer, and modelled values were higher than those measured with passive samplers, while during winter and autumn the results were vice versa. The greatest difference between measured and modelled concentrations of $\mathrm{NO}_{2}$ was determined in winter, while the highest degree of agreement was assessed in summer. We found a strong positive correlation between the measurements and modelling results. The research demonstrates the importance of considering the urban micro environments such as street canyons for the effective assessment of human exposure to transport-related emissions.
\end{abstract}

Keywords: urban pollution; street canyon; nitrogen dioxide; Airviro model; passive sampling

\section{Introduction}

Although fuel and engine technology are rapidly improving, vehicular emissions still are one of the largest anthropogenic sources of pollution in urban areas. Road transport emits many types of pollutants and one of the most important vehicular emissions

*e-mail: audrius.dedele@vdu.lt causing adverse effects on human health, especially in urban areas, are nitrogen oxides $\left(\mathrm{NO}_{\mathrm{x}}\right)$ [1-4]. Long-term exposure to nitrogen dioxide $\left(\mathrm{NO}_{2}\right)$ can increase the risk of respiratory infections, chronic bronchitis, asthma and lung cancer [5-7]. The increased levels of $\mathrm{NO}_{2}$ are observed near intensive traffic congestion or in street canyons, but only about $10-30 \%$ of the primary nitrogen dioxide is emitted directly from cars, while the rest is produced from atmospheric oxidation of nitrogen oxide by a reaction with ozone [8-10]. 
A street canyon is a relatively narrow street flanked by multi-storey buildings on both sides with $\mathrm{s}$ specific microclimate that influences the dispersion of air pollutants [11, 12]. Traffic exhausts are trapped near the ground level because of the complex conditions in urban street canyons [3, 4, 13]. Pollution is not effectively diluted and dispersed in this type of street, therefore residents passing through street canyons are exposed to higher concentrations of air pollutants $[11,14,15]$. The concentration level and dispersion of trafficrelated pollutants inside the street canyon are mainly influenced by traffic and building characteristics, the dimensions of the street canyon, the intersections, urban background concentration above roof level, meteorological and inflow conditions [7, 12, 16, 17]. In order to manage traffic flows, in order to forecast the levels of air pollutants and to assess public exposure, various parametric and numerical street canyon models are used [7, 12]. Modelling along with monitoring is a powerful and widely used tool that allows for a better assessment of the spatial distribution of pollutants [8]. The Airviro is a commonly used Gaussian model for air pollution dispersion modelling, air quality management, different emission scenarios simulation and environmental impact assessment. The Airviro system has been used for several evaluation studies [18-20] and it has been validated against the annual predicted $\mathrm{NO}_{2}$ concentrations and real measurements [21].

The objectives of this study were to measure air pollution of $\mathrm{NO}_{2}$ by passive samplers in five street canyon sites with different traffic and building characteristics during two-week measurement periods in each season and to compare measured $\mathrm{NO}_{2}$ concentrations modelled with Airviro Street Canyon models in Kaunas, Lithuania. Our study has advantages over the previous similar ones because the geographical position of the study area allows for good assessment of seasonality as the concentration of pollutants is being influenced by seasonal differences and the study results can be applied to the eastern and northern European countries. Five typical street canyons were selected for the measurements and modelling of $\mathrm{NO}_{2}$, two measurement sites were in the city centre and three measurement sites were in the Old Town. The selected street canyons have typical unidentical geometrical configurations and they are representative of the general road network in the city centre.

\section{Material and Methods}

Description of the study area and measurement sites

Kaunas is the second-largest city in Lithuania with the population of around 300,000 inhabitants. It is located in the central part of the country and covers $157 \mathrm{~km}^{2}$. Traffic is the biggest source of air pollution, responsible for about 75 percent of total air pollution in the city [22].

Most of the relatively narrow streets surrounded by tall buildings, called street canyons, are located in the city centre and the Old Town dominated by the highest density. To evaluate air pollution in street canyons, the measurements of $\mathrm{NO}_{2}$ were conducted, and street canyon modelling was performed in 5 selected sites in Kaunas (Fig. 1) during each season, according to the traffic and

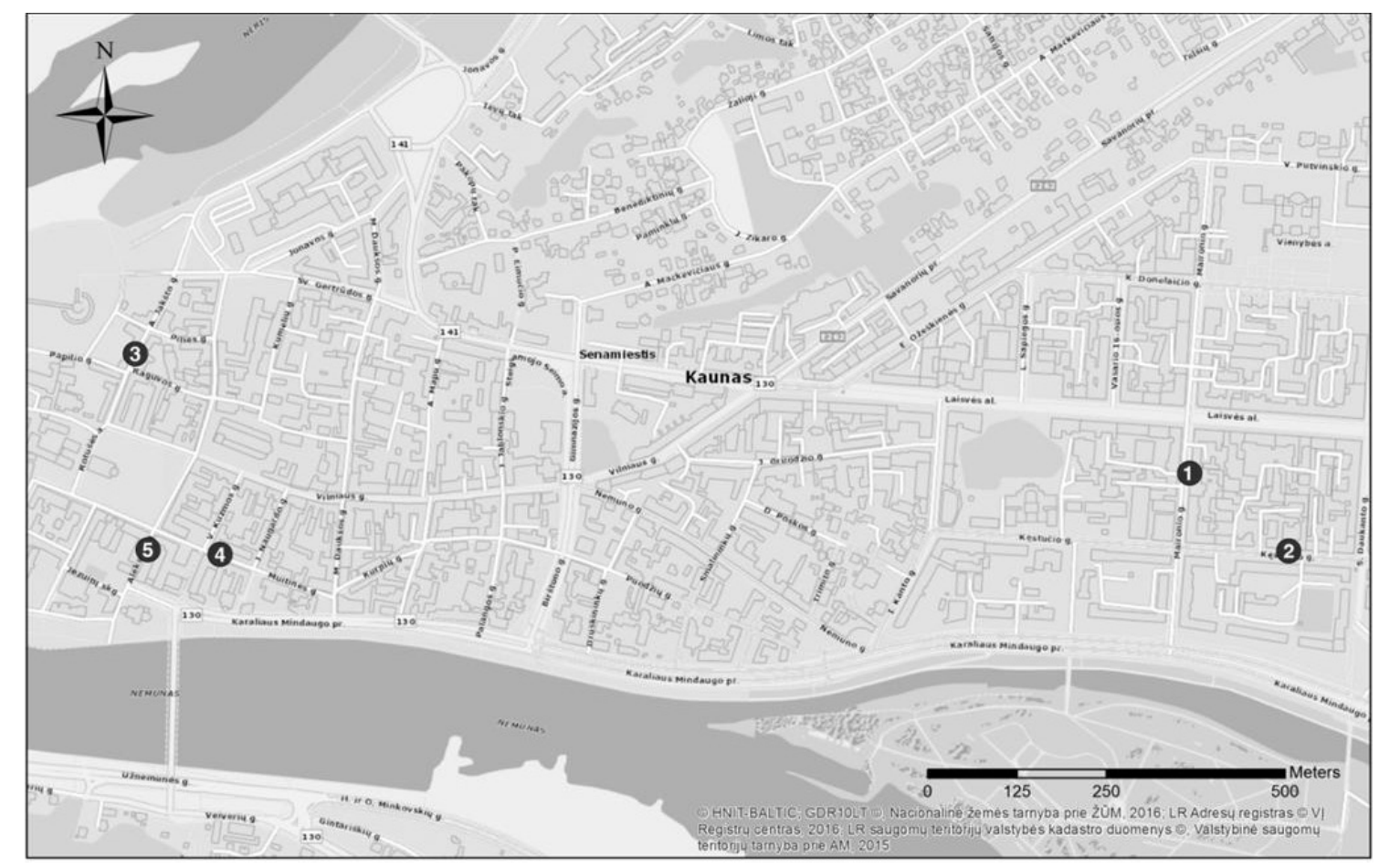

Fig. 1. Measurement sites of street canyons in Kaunas. 
Table 1. Sata of traffic flow and geometries of street canyon sites.

\begin{tabular}{|c|c|c|c|c|c|c|}
\hline Street canyon & Traffic flow (\% of heavy traffic) & H/W & L/H & W & H & L \\
\hline Site 1 (Maironio St.) & $10,700(4 \%)$ & 0.75 & 10.7 & 20 & 15 & 160 \\
\hline Site 2 (Kęstučio St.) & $6,100(20 \%)$ & 0.6 & 19.8 & 20 & 12 & 238 \\
\hline Site 3 (Jakšto St.) & $6,111(8 \%)$ & 1.5 & 14.2 & 8 & 12 & 170 \\
\hline Site 4 (Muitinès St.) & $3,900(8 \%)$ & 1.0 & 30.3 & 8 & 8 & 242 \\
\hline Site 5 (Aleksoto St.) & $3,000(8 \%)$ & 0.89 & 8.8 & 9 & 8 & 70 \\
\hline
\end{tabular}

building characteristics. Two measurement sites were in the city centre near the Kaunas City Municipality and three measurement sites were selected in the Old Town. The most important geometrical details about the street canyon are the ratio of the canyon height $(\mathrm{H})$ to canyon width $(\mathrm{W}), \mathrm{H} / \mathrm{W}$, and the ratio of canyon length (L) to canyon height, $\mathrm{L} / \mathrm{H}[23,24]$. A canyon might be defined as a regular canyon if it has an $\mathrm{H} / \mathrm{W}$ ratio of between 0.5 and 2 . Larger streets with $\mathrm{H} / \mathrm{W}$ ratio below 0.5 can be called avenue canyons, while streets with an $\mathrm{H} / \mathrm{W}$ ratio of 2 and higher might be defined as deep canyons. The length of the street canyon is defined as the road distance between two major intersections. Street canyons according to the $\mathrm{L} / \mathrm{H}$ ratio are subdivided into three categories: short canyons $(\mathrm{L} / \mathrm{H}$ about 3 ), medium ( $\mathrm{L} / \mathrm{H}$ about 5$)$, and long canyons $(\mathrm{L} / \mathrm{H}$ about 7). The data of traffic volume and geometrical details of five street canyon sites are presented in Table 1. Traffic volume at five street canyon sites was estimated by directly counting the number of lightduty and heavy-duty vehicles (trucks and buses) from $9.00 \mathrm{am}$ to $4.00 \mathrm{pm}$ (trying to avoid the peak hours) on weekdays. Traffic flow data were used to calculate average daily traffic counts.

The first two sites (Maironio and Kęstučio Streets) are located in the central part of the city. Maironio Street (Site 1) is a busy two-lane road that is orientated north-south. Kęstučio Street (Site 2) is a two-lane road with one-way traffic orientated east-west.

All other sites (Jakšto, Muitinès and Aleksoto Streets) are located in the Old Town. Jakšto Street (Site 3 ) is a two-lane narrow road with a north-northeastsouth-southwest orientation. Muitinès Street (Site 4) is a two-lane narrow road with a one-way traffic restriction orientated east-southeast-west-northwest. Aleksoto Street (Site 5) is $7 \mathrm{~m}$ wide with a north-northeast-southsouthwest orientation.

\section{The Measurements of Nitrogen Dioxide}

The sampling was conducted in 2012 in Kaunas. All measurements were taken continuously over the two-week sampling period during each season and simultaneously at five street canyons. Passive sampling technique, which is based on the molecular diffusion of gases, has been used to measure the concentration of
$\mathrm{NO}_{2}$ in selected street canyon sites. A passive sampler consisted of a filter paper that was impregnated with triethanolamine (TEA) and placed in the sampler's bottom [25]. Two passive samplers were placed in each of the five sites of street canyon. Ten passive samplers were exposed for two-week measurement periods in each season (40 passive samplers during the entire study period). Samplers were hanged at $3.5 \mathrm{~m}$ above ground level. After exposure, samplers were collected and transferred to the lab for analysis. The average concentration of $\mathrm{NO}_{2}$ was determined after extraction and analysis using the spectrophotometric Saltzman method [26, 27].

\section{Street Canyon Modelling}

The Airviro is a dispersion simulation system developed by the Swedish Meteorological and Hydrological Institute (SMHI), including Gaussian plume and street canyon models, emission inventories and large amounts of data handling. The street canyon model in Airviro is a small-scale model used to simulate concentrations of $\mathrm{NO}_{2}$ at five street canyons over the same two-week period in each season as the measurements. The Airviro model has an integrated chemical reaction model based on the existence of a statistical relationship between the $\mathrm{NO}_{2} / \mathrm{NO}_{x}$ ratio to the absolute $\mathrm{NO}_{\mathrm{x}}$ level $[28,29]$. The street canyon model input parameters were the characteristics of buildings (the distance between buildings and the height of buildings on each side of the street canyon) and the characteristics of streets (width, direction and position). The model assumes that the height of the buildings on both sides of the street canyon is the same. The expressions for the upwind (CL) and downwind (CW) sides are used in the Airviro model. The equations of the pollutant concentration on the CL (Eq. 1) and the $\mathrm{CW}$ (Eq. 2) are presented below according to Airviro specification v. 3.20.

$$
C L=\frac{\mathrm{K} \cdot \mathrm{Q}}{\left(\mathrm{u}+0.5 \cdot\left[\left(x^{2}+y^{2}\right)^{\frac{1}{2}}+L_{0}\right]\right.}\left(0.27 \cdot u-0.016 \cdot u^{2}+0.65\right)
$$

$$
C W=\frac{\mathrm{K} \cdot \mathrm{Q} \cdot(H-z)}{\mathrm{W} \cdot(u+0.5) \cdot H}
$$


...where $K$ is an empirical constant set to $14 ; Q$ is the traffic emission in $\mathrm{g} /(\mathrm{m}, \mathrm{s}) ; u$ is the wind component perpendicular to the street axis, in $\mathrm{m} / \mathrm{s} ; L_{0}$ is a length scale of the individual cars, set to $2 \mathrm{~m} ; W$ is width between the houses; $H$ the typical house height in $\mathrm{m}$; and $\mathrm{x}$ and $\mathrm{z}$ are horizontal and vertical distances from the street emission segments.

Emissions from road transport were specified by defining the number of light- and heavy-duty vehicles and the average driving speed in each street segment. Urban background concentrations were taken into account in order to obtain accurate and reliable modelling results. Urban background air pollution of $\mathrm{NO}_{2}$ was evaluated by adding a uniform annual value that was obtained from the U.S. Environmental Protection Agency (EPA) to the final modelling results.

\section{Meteorological Data}

Hourly sequential meteorological data of wind speed $(\mathrm{m} / \mathrm{s})$, wind direction $\left(0-360^{\circ}\right)$, surface temperature $\left({ }^{\circ} \mathrm{C}\right)$, relative humidity $(\%)$ and temperature inversion $\left({ }^{\circ} \mathrm{C}\right)$ for 2012 were obtained from Kaunas Meteorological Station and used for street canyon modelling in this study. The data of wind speed and wind direction are one of the most important meteorological parameters for street canyon modelling as the distribution of air pollution depends on the wind direction with respect to street orientation.
Plots of wind roses for two-week periods in each season are presented in Fig. 2. Wind rose of winter tends to indicate that the dominant wind direction was from southeast. The average wind speed of $3.8 \mathrm{~m} / \mathrm{s}$ was observed in winter with the maximum value of $8.2 \mathrm{~m} / \mathrm{s}$. The highest wind speed (more than $6 \mathrm{~m} / \mathrm{s}$ ) mostly blew from the southeast. The winds in spring mostly blew from the west. The average wind speed in spring was $2.7 \mathrm{~m} / \mathrm{s}$. The strongest winds were recorded from the southeast with the maximum value of $8.4 \mathrm{~m} / \mathrm{s}$. Although during the summer wind direction was ambiguous, the most frequently wind direction was from the southeast. The average wind speed was $2.4 \mathrm{~m} / \mathrm{s}$ and the maximum observed value of wind speed was $6.3 \mathrm{~m} / \mathrm{s}$. The predominant wind direction in autumn was from the southeast. The lowest average wind speed was observed during autumn, at $2.9 \mathrm{~m} / \mathrm{s}$. The maximum recorded value of wind speed was $6.9 \mathrm{~m} / \mathrm{s}$.

\section{Statistical Analysis}

The data analysis and the comparison of measurements and modelling results were made using statistical analysis software package SPSS (Version 18.0, SPSS Inc., Chicago). Concentrations of $\mathrm{NO}_{2}$ calculated by the Airviro model have been compared with measurements made by passive samplers at five street canyons by calculating these statistical measurements: the mean and the standard error of mean (SE), the
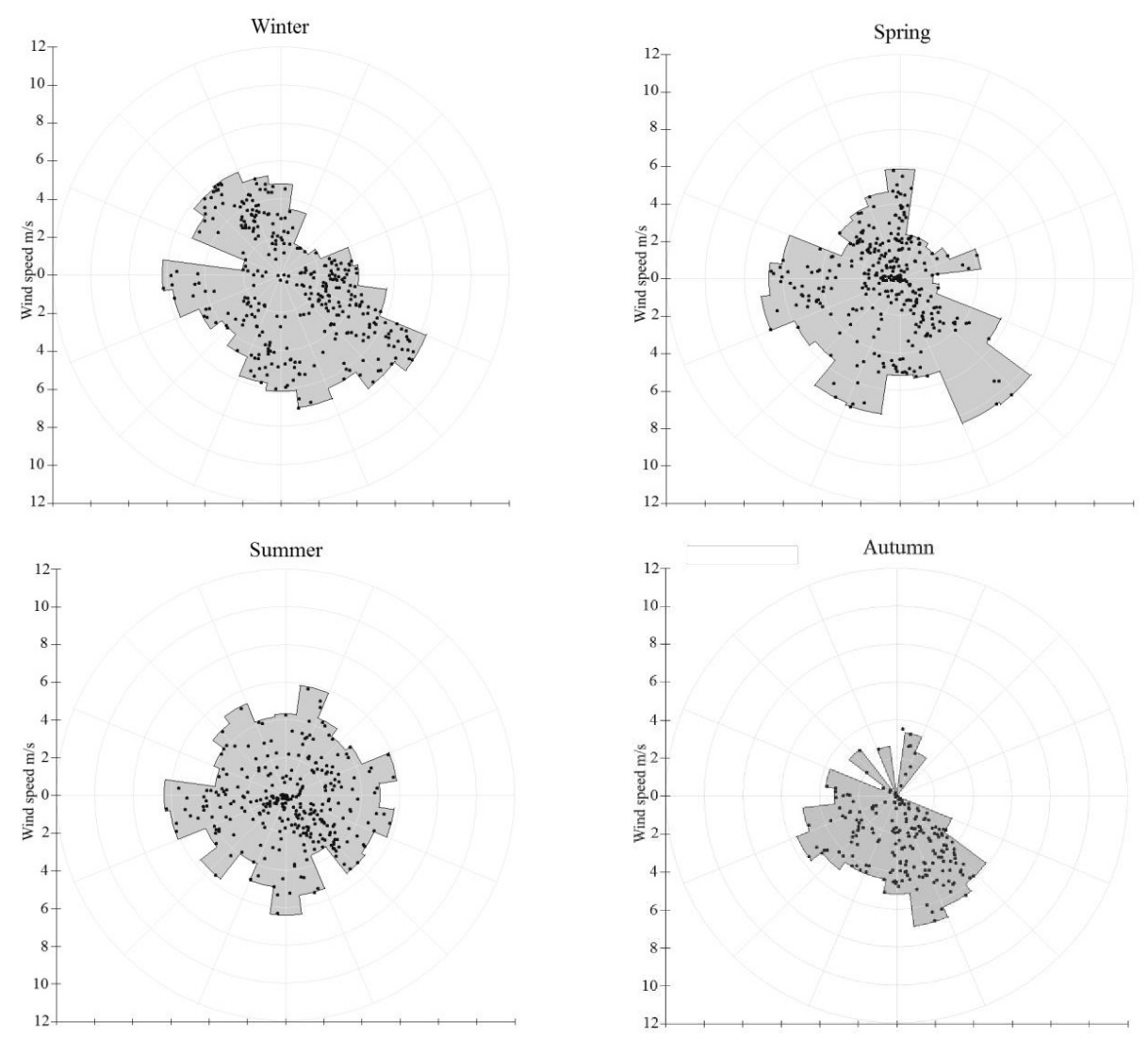

Fig. 2. Wind rose plots for two-week periods in each season during 2012 (dots indicate wind speed $(\mathrm{m} / \mathrm{s})$ and wind direction $\left.\left(0-360^{\circ}\right)\right)$ 
mean bias (MB) (Eq. 3), the fractional bias (FB) (Eq. 4), the geometric mean bias (MG) (Eq. 5), the geometric variance (VG) (Eq. 6), the root mean square error (RMSE) (Eq. 7) and the index of agreement (d) (Eq. 8) based on previous studies [30-34]:

$$
\begin{gathered}
M B=\left(C_{o}-C_{m}\right) \\
F B=\frac{\left(\bar{C}_{o}-\bar{C}_{m}\right)}{0.5\left(\bar{C}_{o}+\bar{C}_{m}\right)} \\
M G=\exp \left(\overline{\ln C_{o}}-\overline{\ln C_{m}}\right) \\
V G=\exp \left[\overline{\left(\ln C_{o}-\ln C_{m}\right)^{2}}\right] \\
R M S E=\sqrt{\frac{1}{N} \sum_{i=1}^{n}\left(C_{o, i}-C_{m, i}\right)^{2}} \\
d=1-\frac{\sum_{i=1}^{N}\left(C_{m}^{i}-C_{o}^{i}\right)^{2}}{\sum_{i=1}^{N}\left(\left|C_{m}^{i}-\overline{C_{o}}\right|+\left|C_{o}^{i}-\overline{C_{o}}\right|\right)^{2}}
\end{gathered}
$$

...where $C_{o}$ denotes measured values, $C_{m}$ denotes modelled values, and overbar $(\overline{\mathrm{C}})$ denotes the average over the dataset. A perfect model would have the MB, $\mathrm{FB}, \mathrm{RMSE}=0.0$ and $\mathrm{MG}, \mathrm{VG}, \mathrm{d}=1.0$. A detailed description of these statistical measurements can be found in our previous study [30].
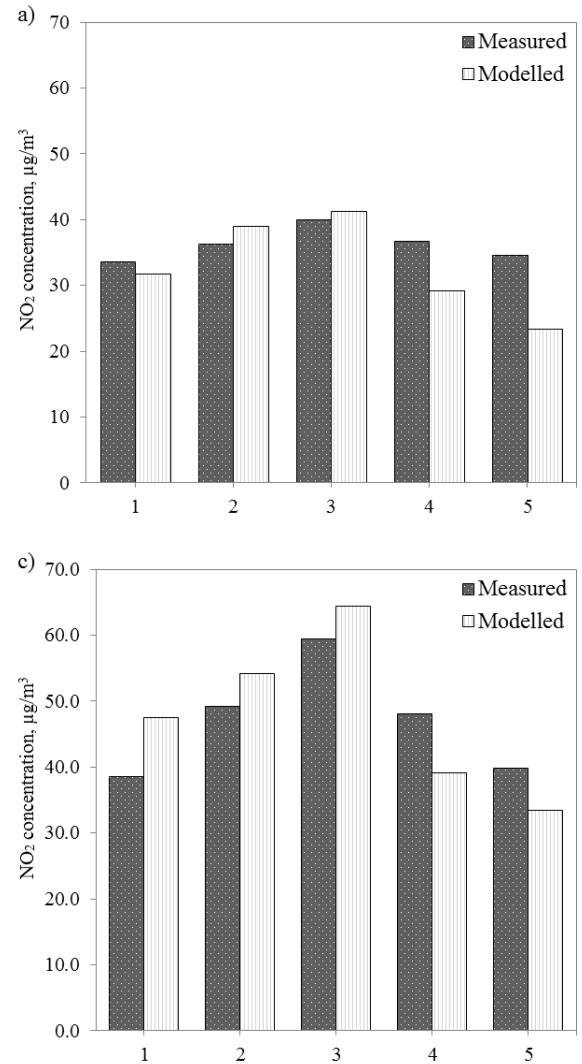

\section{Results and Discussion}

The results of measurements and modelling at five street canyon sites over two-week periods in each season are shown below (Fig. 3). The highest concentration of $\mathrm{NO}_{2}$ during winter season was measured and modelled in site 3 , respectively 40.0 and $41.3 \mu \mathrm{g} / \mathrm{m}^{3}$. The lowest measured $\mathrm{NO}_{2}$ concentration was determined in site 1 , while the model was estimated in site 5 , respectively 33.5 and $23.4 \mu \mathrm{g} / \mathrm{m}^{3}$.

The highest measured and modelled concentrations of $\mathrm{NO}_{2}$ in spring and summer were observed in the same measurement site as in winter (site 3). The measured values were 53.2 and $59.4 \mu \mathrm{g} / \mathrm{m}^{3}$ and modelled values 66.0 and $64.4 \mu \mathrm{g} / \mathrm{m}^{3}$ during spring and summer, respectively. The lowest measured $\mathrm{NO}_{2}$ concentrations during spring and summer were observed in site 1 , respectively 32.5 and $38.6 \mu \mathrm{g} / \mathrm{m}^{3}$, while the lowest modelled concentrations of $\mathrm{NO}_{2}\left(30.1\right.$ and $\left.33.4 \mu \mathrm{g} / \mathrm{m}^{3}\right)$ were estimated in site 5 .

In autumn the highest measured $\mathrm{NO}_{2}$ concentration of $46.8 \mu \mathrm{g} / \mathrm{m}^{3}$ was observed in site 4 , while the highest modelled concentration of $57.1 \mu \mathrm{g} / \mathrm{m}^{3}$ was determined in site 3 . The lowest measured $\left(39.2 \mu \mathrm{g} / \mathrm{m}^{3}\right)$ and modelled $\left(30.6 \mu \mathrm{g} / \mathrm{m}^{3}\right) \mathrm{NO}_{2}$ concentrations were assessed in site 5 .

The analysis of seasonal measurements made over two-week periods and modelling results of $\mathrm{NO}_{2}$ concentrations averaged over all street canyon sites
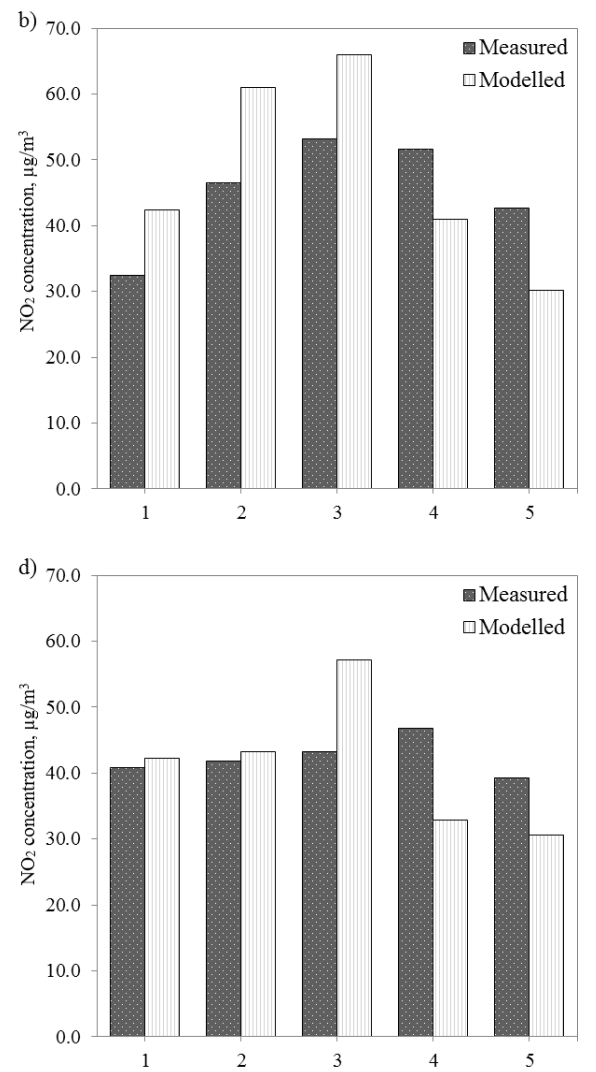

Fig. 3. Concentration of $\mathrm{NO}_{2}$ measured with passive samplers and modelled with Airviro street canyon model at 5 sites (x-axis): a) winter, b) spring, c) summer, d) autumn. 


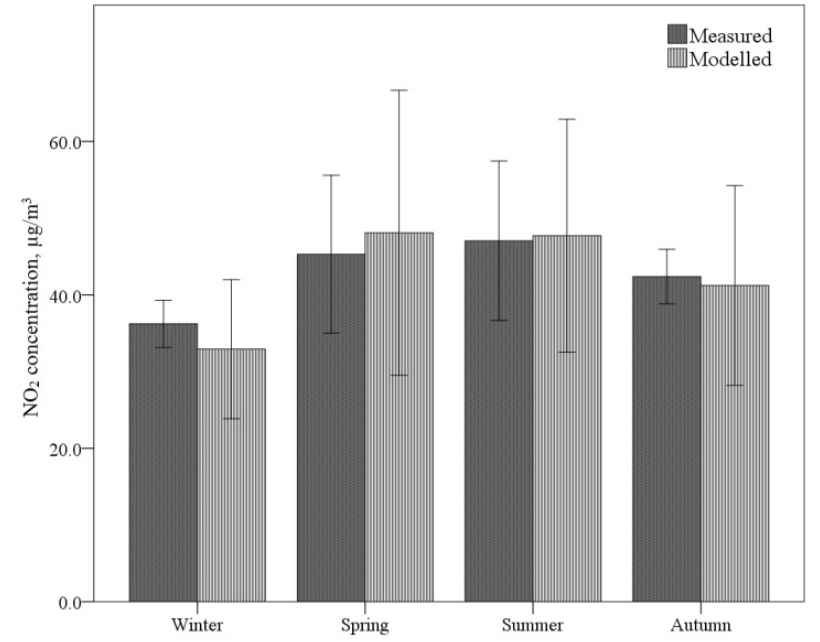

Fig. 4. Seasonal measured and modelled concentrations of $\mathrm{NO}_{2}$ averaged over all street canyon sites.

showed that the highest $\mathrm{NO}_{2}$ concentrations were observed in spring and summer (Fig. 4). The highest measured concentration of $\mathrm{NO}_{2}$ was observed during summer $\left(47.0 \mu \mathrm{g} / \mathrm{m}^{3}\right)$, while the highest modelled concentration of $\mathrm{NO}_{2}$ was estimated during spring $\left(48.1 \mu \mathrm{g} / \mathrm{m}^{3}\right)$. The lowest measured and modelled concentrations of $\mathrm{NO}_{2}$ were determined in winter, respectively 36.2 and $32.9 \mu \mathrm{g} / \mathrm{m}^{3}$. The concentration of $\mathrm{NO}_{2}$ measured with passive samplers was higher than that modelled with street canyon model in winter and autumn, while in spring and summer seasons the results were vice versa. The greatest difference between measured and modelled concentrations of $\mathrm{NO}_{2}$ was determined in winter $\left(3.3 \mu \mathrm{g} / \mathrm{m}^{3}\right)$, and this could be due to the domestic heating, which contributes significantly to the total air pollution in the city during winter. The street canyon model does not take into account emissions from the other sources of air pollution, and it might be a reason why measured average concentration of $\mathrm{NO}_{2}$ was higher than modelled. The highest degree of agreement was assessed in summer $\left(-0.7 \mu \mathrm{g} / \mathrm{m}^{3}\right)$. The Univariate Analysis of Variance showed that there was no significant difference in the average concentrations of $\mathrm{NO}_{2}$ between the measurements and modelling results in each season $(\mathrm{p}>0.05)$.

The seasonally averaged concentrations of $\mathrm{NO}_{2}$ measured with passive samplers and modelled with Airviro model at 5 street canyon sites are shown below (Fig. 5). The highest concentration of $\mathrm{NO}_{2}$ was observed in site 3 , measured value was $49.0 \mu \mathrm{g} / \mathrm{m}^{3}$ and modelled value was $57.2 \mu \mathrm{g} / \mathrm{m}^{3}$. This street canyon site had the highest height-to-width ratio $(\mathrm{H} / \mathrm{W}=1.5)$, which could lead to high concentrations of $\mathrm{NO}_{2}$ as relatively narrow street canyons tend to have higher pollution levels because of reduced ventilation, which affects the dispersion of pollutants [35, 36]. The lowest measured $\mathrm{NO}_{2}$ concentration was determined in site 1 $\left(36.4 \mu \mathrm{g} / \mathrm{m}^{3}\right)$, while the lowest modelled concentration

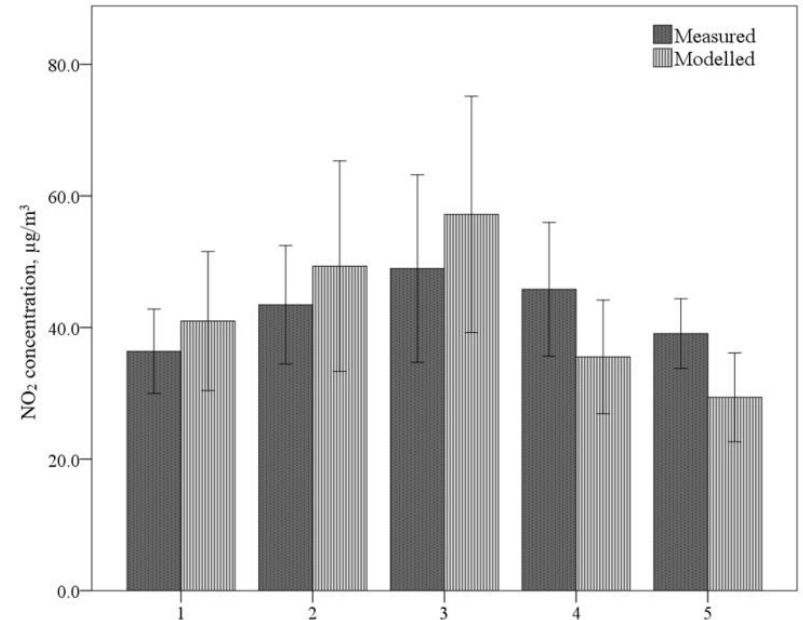

Fig. 5. Averaged concentrations of $\mathrm{NO}_{2}$ measured and modelled at 5 street canyon sites (x-axis).

was estimated in site $5\left(29.4 \mu \mathrm{g} / \mathrm{m}^{3}\right)$. Both sites (1 and 5) had the lowest $\mathrm{H} / \mathrm{W}$ and $\mathrm{L} / \mathrm{H}$ ratios; however, site 1 had the highest traffic flow and site 5 had the lowest traffic flow. These results suggest that the greatest errors of Airviro street canyon modelling results occur in street canyons with the lowest traffic flows.

In three measurement sites $(1,2,3)$ modelled concentrations of $\mathrm{NO}_{2}$ were higher than those measured with passive samplers, while in sites 4 and 5 modelled $\mathrm{NO}_{2}$ concentrations were lower than measured. The highest discrepancy between the measurements and modelling results was assessed in sites 4 and 5. These two street canyon sites had the lowest traffic intensity, however, they both are close to high traffic streets and this could lead to higher measured concentrations than those modelled with street canyon model, in which one of the main limitations are that it could not take into account other surrounding pollution sources while modelling a particular street segment. Also, the annual background value of nitrogen dioxide was used in this study for all street canyon measurement sites, which could lead to some uncertainties as modelling results are sensitive to background data as an input variable [2, 36].

We performed one-way anova analysis to determine if there are any statistically significant differences between the means of measured and modelled $\mathrm{NO}_{2}$ concentrations in 5 street canyon sites. The results of statistical test showed that there were no statistically significant differences between measured and modelled concentrations of $\mathrm{NO}_{2}$ in sites 1,2 and $3(\mathrm{p} \geq 0.28)$, while in sites 4 and 5 we found a difference in $\mathrm{NO}_{2}$ concentrations measured with passive samplers and modelled with street canyon model $(\mathrm{p} \leq 0.05)$.

A more detailed statistical analysis was done to evaluate the performance of the Airviro model to simulate the concentrations of $\mathrm{NO}_{2}$. The comparison of measurements and modelling results at five street canyons was made by calculating the most commonly 
Table 2. Statistical parameters of measured and modelled $\mathrm{NO}_{2}$ concentrationa in street canyon sites.

\begin{tabular}{|c|c|c|c|c|c|c|c|c|}
\hline \multirow{2}{*}{ Site } & \multicolumn{2}{|c|}{ Mean \pm SE } & \multirow{2}{*}{$\mathrm{MB}$} & \multirow{2}{*}{ FB } & \multirow{2}{*}{$\mathrm{MG}$} & \multirow{2}{*}{ VG } & \multirow{2}{*}{ RMSE } & \multirow{2}{*}{ d } \\
\hline & Measured & Modelled & & & & & & \\
\hline 1 & $36.4 \pm 2.01$ & $41.0 \pm 3.32$ & -4.6 & -0.11 & 0.90 & 1.030 & 6.75 & 0.59 \\
\hline 2 & $43.5 \pm 2.83$ & $49.3 \pm 5.03$ & -5.9 & -0.12 & 0.89 & 1.023 & 7.80 & 0.71 \\
\hline 3 & $49.0 \pm 4.48$ & $57.2 \pm 5.64$ & -8.3 & -0.15 & 0.86 & 1.034 & 9.80 & 0.76 \\
\hline 4 & $45.8 \pm 3.20$ & $35.5 \pm 2.72$ & 10.3 & 0.25 & 1.29 & 1.071 & 10.55 & 0.58 \\
\hline 5 & $39.1 \pm 1.66$ & $29.4 \pm 2.12$ & 9.7 & 0.29 & 1.34 & 1.097 & 9.97 & 0.41 \\
\hline
\end{tabular}

used statistical parameters (Table 2). In order to evaluate the agreement between measured and modelled concentrations of $\mathrm{NO}_{2}$ and to assess the accuracy of the model it is important to interpret the statistical results correctly.

The results of statistical analysis showed that the lowest mean bias was determined between measured and modelled concentrations of $\mathrm{NO}_{2}$ in street canyon site 1 , while the highest mean bias was calculated between measured and modelled $\mathrm{NO}_{2}$ values in sites 4 and 5, which differed from other measurement sites because of low traffic flows. The street canyon model overestimated $\mathrm{NO}_{2}$ with the mean bias of $4.6,5.9$ and $8.3 \mu \mathrm{g} / \mathrm{m}^{3}$ in sites 1, 2 and 3, respectively, and underestimated $\mathrm{NO}_{2}$ with the mean bias of 10.3 and $9.7 \mu \mathrm{g} / \mathrm{m}^{3}$ in sites 4 and 5 , respectively. The annual FB showed model over prediction of $0.11,0.12$ and 0.15 , respectively, in sites 1 , 2 and 3 and under prediction of 0.25 and 0.29 in sites 4 and 5 , respectively.

MG greater than 1 was calculated in measurement sites 4 and 5, which implies that the street canyon model underestimated the concentration of $\mathrm{NO}_{2}$. The model overestimation was determined in sites 1,2 and 3 .

The calculation results of $\mathrm{VG}$ indicated that the difference between measured and modelled concentrations of $\mathrm{NO}_{2}$ was closest to 1 in measurement sites 1, 2 and 3, respectively, 1.030, 1.023 and $1.034 \mu \mathrm{g} / \mathrm{m}^{3}$.

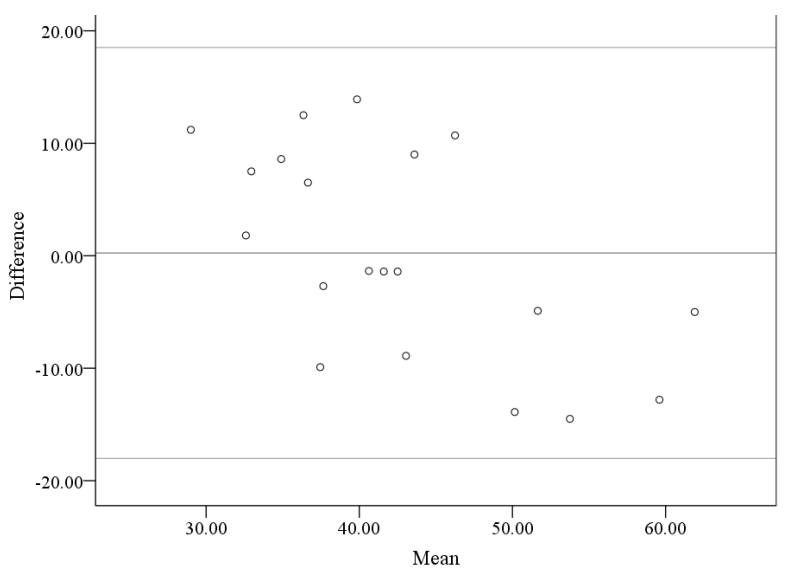

Fig. 6. A Bland-Altman plot of differences between measured and modelled concentrations of $\mathrm{NO}_{2}$ vs. means.
RMSE indicates the fit of the model data to the real measurements. The smallest RMSE value between measured and modelled $\mathrm{NO}_{2}$ concentrations was calculated in site $1\left(\mathrm{RMSE}=6.75 \mu \mathrm{g} / \mathrm{m}^{3}\right)$, while the largest value of RMSE was assessed in measurement site $4\left(\mathrm{RMSE}=10.55 \mu \mathrm{g} / \mathrm{m}^{3}\right)$, which resulted in higher standard errors.

The index of agreement (d) ranges from 0 to 1 with higher values indicating better agreement between measured and modelled concentrations. A good agreement was obtained between measured and modelled $\mathrm{NO}_{2}$ concentrations in street canyon sites 2 and 3. The index of agreement in these street canyon sites were 0.71 and 0.76 , respectively. The greatest difference between the measurements and modelling results was calculated in street canyon site 5 with the value of 0.41 .

The correlation coefficient was also calculated to assess the linear relationship between measured and modelled values of $\mathrm{NO}_{2}$ in street canyons. The results showed a statistically significant strong positive correlation $(\mathrm{r}=0.66 ; \mathrm{p}=0.001)$.

The Bland-Altman plot shows the relationship of the differences between the measurements made by passive samplers and modelling results (Fig. 6). Horizontal lines indicate the mean difference, and the $95 \%$ confidence intervals. The mean difference between measured and modelled concentrations of $\mathrm{NO}_{2}$ in five street canyon sites was $0.25 \pm 2.08 \mu \mathrm{g} / \mathrm{m}^{3}$. All values were between $95 \%$ confidence intervals, which leads to the conclusion that there was no statistically significant difference between modelled and measured concentrations of $\mathrm{NO}_{2}$.

We calculated One Sample t-test for difference score, which showed that there is some level of agreement between the measurements and modelling results $(\mathrm{p}=0.91)$.

\section{Conclusions}

In this study, the evaluation of air pollution of $\mathrm{NO}_{2}$ was assessed in 5 street canyon sites during two-week periods in each season and the comparison between measurements and modelling results were made in order to evaluate the performance of the Airviro street canyon model. 
The highest measured and modelled concentrations of $\mathrm{NO}_{2}$ were determined in spring and summer, and it could be related to increased traffic in the city, especially in the central part of it, and certain seasonal meteorological conditions. The highest values of $\mathrm{NO}_{2}$ were assessed in street canyon site 3 , which is in Old Town and has a relatively narrow width with the highest $\mathrm{H} / \mathrm{W}$ ratio of 1.5 . The comparison of measurements and modelling results revealed that the Airviro model overestimated $\mathrm{NO}_{2}$ concentrations in measurement sites with medium and high traffic intensity and underestimated the values of $\mathrm{NO}_{2}$ in street canyons with low traffic intensity (sites 4 and 5). These results suggest that more detailed attention should be given by considering urban background concentrations, which might increase the accuracy of the modelling results.

The comparison between measured and modelled concentrations of $\mathrm{NO}_{2}$ showed that the Airviro street canyon model can be applied to the prediction of trafficrelated air pollution in street canyons and reliably used for urban planning and the improvement of air quality and traffic management. Statistical analysis showed that the smallest mean difference and the lowest RMSE between measured and modelled $\mathrm{NO}_{2}$ values were determined in street canyons with the highest traffic intensity, while the greatest difference and the highest RMSE were calculated in street canyons with the lowest traffic intensity (sites 4 and 5).

The discrepancy between measurements and modelling results may be due to the uncertainties in emission factors or input data of traffic counts or changes in seasonal variation in traffic flows, which the Airviro model does not take into account. It would have been better to have hourly values of urban background concentrations of the modelled pollutant instead of uniform annual value, because it might give slightly more accurate results and better agreement between measured and modelled concentrations of $\mathrm{NO}_{2}-$ especially in street canyon sites with low traffic intensity, as these sites may be more influenced by urban background pollution. It can be considered as a limitation of the study. Accounting for urban background concentrations of $\mathrm{NO}_{2}$ may reduce some of the overestimation of concentrations. There are the complexities of dispersion in street canyons related with the angle of the wind to the length of the canyon and more detailed analysis in the future research is needed to understand the impact of street canyon configurations on pollutant dispersion and to evaluate interactions between different factors, such as meteorological parameters, the characteristics of street buildings and urban air pollution, that influence the concentration variations of $\mathrm{NO}_{2}$.

\section{Acknowledgements}

Authors would like to thank the Division of Environmental Protection of Kaunas City Municipality for giving us access to the dataset of air pollution.

\section{Conflict of Interest}

The authors declare no conflict of interest.

\section{References}

1. MAZZEO N.A., VENEGAS L.E. Evaluation of natural and traffic-producing turbulences using full scale data from four street canyons. Cro Met J. 43, 662, 2008.

2. VARDOULAKIS S., FISHER B.E.A., PERICLEOUS K., GONZALEZ-FLESCA N. Modelling air quality in street canyons: a review. Atmos Environ. 37, 155, 2003.

3. VINTAR MALLY K., OGRIN M. Spatial variations in nitrogen dioxide concentrations in urban Ljubljana, Slovenia. Morav Geogr Rep. 23, 27, 2015.

4. YAZID A.W.M., SIDIK N.A.C., SALIM S.M., SAQR K.M. A review on the flow structure and pollutant dispersion in urban street canyons for urban planning strategies. Simul Gaming. 90, 892, 2014.

5. BELANGER K., HOLFORD T.R., GENT J.F., HILL M.E., KEZIK J.M., LEADERER B.P. Household levels of nitrogen dioxide and pediatric asthma severity. Epidemiology. 24, 320, 2013.

6. CLARK N.A., DEMERS P.A., KARR C.J., KOEHOORN M., LENCAR C., TAMBURIC L., BRAUER M. Effect of Early Life Exposure to Air Pollution on Development of Childhood Asthma. Environ Health Perspect. 118, 284, 2010.

7. SATHE YOGESH V. Air quality modeling in street canyons of Kolhapur city, Maharashtra, India. Univers J Environ Res Technol. 2, 97, 2012.

8. KIM M.J., PARK R.J., KIM J.J. Urban air quality modeling with full $\mathrm{O}_{3}-\mathrm{NO}_{\mathrm{x}}$-VOC chemistry: Implications for $\mathrm{O}_{3}$ and PM air quality in a street canyon. Atmos Environ. 47, 330, 2012.

9. RAASCHOU-NIELSEN O., HERTEL O., VIGNATI E., BERKOWICZ R., JENSEN S.S., LARSEN V.B., LOHSE C., OLSEN J.H. An air pollution model for use in epidemiological studies: evaluation with measured levels of nitrogen dioxide and benzene. J Expo Anal Environ Epidemiol. 10, 4, 2000.

10. YAO X., LAU N.T., CHAN C.K., FANG M. The use of tunnel concentration profile data to determine the ratio of $\mathrm{NO}_{2} / \mathrm{NO}_{x}$ directly emitted from vehicles. Atmos Chem Phys Discuss. 5, 12723, 2005.

11. MIAO Y., LIU S., ZHENG Y., WANG S., LI Y. Numerical study of traffic pollutant dispersion within different street canyon configuration. Adv Meteorol. 2014, $1,2014$.

12. VENEGAS L.E., MAZZEO N.A., DEZZUTTI M.C. A simple model for calculating air pollution within street canyons. Atmos Environ. 87, 77, 2014.

13. BALCZÓ M., GROMKE C., RUCK B. Numerical modeling of flow and pollutant dispersion in street canyons with tree planting. Meteorol Z. 18, 197, 2009.

14. RÁCZ Ė.V.P., HORVÁTH Z. Small-scale differences of urban NOx exposition in field measurement data. The Sustainable City IX. 2, 1513, 2014.

15. ZHOU Y., LEVY J.I. The impact of urban street canyons on population exposure to traffic-related primary pollutants. Atmos Environ. 42, 3087, 2008.

16. MAZZEO N.A., VENEGAS L.E., MARTIN P.B. Analysis of full-scale data obtained in a street canyon. Atmósfera. 20, 93, 2007. 
17. PARK S.J., KIM J.J., KIM M.J., PARK R.J., CHEONG H.B. Characteristics of flow and reactive pollutant dispersion in urban street canyons. Atmos Environ. 108, 20, 2015 .

18. GIDHAGEN L., JOHANSSON H., OMSTEDT G. SIMAIR - evaluation tool for meeting the EU directive on air pollution limits. Atmos Environ. 43, 1029, 2009.

19. HAGGMARK L., IVARSSON K.I., GOLLVIK S., OLOFSSON P.O. Mesan, an operational mesoscale analysis system. Tellus A. 52, 2, 2000.

20. OMSTEDT G., ANDERSSON S., GIDHAGEN L., ROBERTSON L. Evaluation of new model tools for meeting the targets of the EU Air Quality Directive: a case study on the studded tyre use in Sweden. Int J Environ Pollut. 47, 79, 2011.

21. JENKINSON P., HILL R., LUTMAN E. Validation of The Airviro Gaussian Plume And Street Canyon Model For The Prediction Of $\mathrm{NO}_{x}$ And $\mathrm{NO}_{2}$ Concentrations Arising From Road Traffic. 11th International Conference on Harmonisation within Atmospheric Dispersion Modelling for Regulatory Purposes. July 2-5, 53, Cambridge, United Kingdom, 2007.

22. GRABYS J., USOVAITE A., GASPARIUNAS J. Environmental pollutants emission from public transport assessment and analysis in Vilnius city. The $8^{\text {th }}$ International Conference Environmental Engineering: Selected papers. Ed. by Čygas D, Froehner KD. Vilnius: Technika. May 19-20, 893, Vilnius, Lithuania, 2011.

23. AFIQ W.M.Y., AZWADI C.S.N., SAQR K.M. Effects of buildings aspect ratio, wind speed and wind direction on flow structure and pollutant dispersion in symmetric street canyons: a review. Int J Mech Mater Eng. 7, 158, 2012.

24. BAKARMAN M.A., CHANG J.D. The Influence of Height/width Ratio on Urban Heat Island in Hot-arid Climates. Procedia Eng. 118, 101, 2015.

25. KROCHMAL D., GORSKI L. Determination of nitrogen dioxide in ambient air by use of a passive sampling technique and triethanolamine as absorbent. Environ Sci Technol. 25, 531, 1991.

26. BYANJU R.M., GEWALI M.B., MANANDHAR K. Passive sampling of ambient nitrogen dioxide using local tubes. J Environ Prot. 3, 177, 2012.

27. KROCHMAL D., KALINA A. Measurements of nitrogen dioxide and sulphur dioxide concentrations in urban and rural areas of Poland using a passive sampling method. Environ Pollut. 96, 401, 1997.

28. NAMDEO A., MITCHELL G., DIXON R. TEMMS: an integrated package for modelling and mapping urban traffic emissions and air quality. Environ Model Softw. 17, 177, 2002.

29. SMHI. SMHI Airviro Swedish Meteorological and Hydrological Institute. Available online: http://www.smhi. se/airviro. Accessed 14 February 2017.

30. DĖDELE் A., MIŠKINYTE் A. The statistical evaluation and comparison of ADMS-Urban model for the prediction of nitrogen dioxide with air quality monitoring network. Environ Monit Assess. 187, 578, 2015.

31. BENNETT N.D., CROKE B.F.W., GUARISO G., GUILLAUME J.H.A., HAMILTON S.H., JAKEMAN A.J., MARSILI-LIBELLI S., NEWHAMA L.T.H., NORTON J.P., PERRIN C., PIERCE S.A., ROBSON B., SEPPELT R., VOINOV A.A., FATH B.D., ANDREASSIAN V. Characterising performance of environmental models. Environ Model Softw. 40, 1, 2013.

32. LEGATES D.R., MCCABE G.J. Evaluating the use of "goodness-of-fit" Measures in hydrologic and hydroclimatic model validation. Water Resour Res. 35, 233, 1999.

33. ROJAS A.L.P. Simple atmospheric dispersion model to estimate hourly ground-level nitrogen dioxide and ozone concentrations at urban scale. Environ Model Softw. 59, 127, 2014.

34. ZHU G., ZHANG P., TSHUKUDU T., YIN J., FAN G., ZHENG $X$. Forecasting traffic-related nitrogen oxides within a street canyon by combining a genetic algorithmback propagation artificial neural network and parametric models. Atmos Pol Res. 6, 1087, 2015.

35. EEFTENS M., BEEKHUIZEN J., BEELEN R., WANG M., VERMEULEN R., BRUNEKREEF B., HUSS A., HOEK G. Quantifying urban street configuration for improvements in air pollution models. Atmos Environ. 72, $1,2013$.

36. VARDOULAKIS S., VALIANTIS M., MILNER J., APSIMON H. Operational air pollution modelling in the UK - Street canyon applications and challenges. Atmos Environ. 41, 4622, 2007. 